\title{
EFFECTIVENESS OF THE USE OF MAP MEDIA AGAINST SPATIAL LITERACY OF CLASS V ELEMENTARY SCHOOL STUDENTS IN SOCIAL STUDIES (IPS) LEARNING
}

(Quasi Study Experiments for Class V Students of SDN 10 Metro Timur, SDN 5 Metro Selatan, SDN 4 Metro Utara and SDN 6 Metro Pusat)

\author{
Dicky Prastya $^{1)}$, Winda Maharani ${ }^{1)}$ \\ ${ }^{*}$ STKIP PGRI Metro, Lampung, Indonesia \\ Corresponding Author: maharaniwinda21@gmail.com
}

\begin{abstract}
This research is motivated by the lack of utilization of the media in conducting learning related to space, making spatial literacy of students less explored. In addition, students tend to be more passive and bored quickly when the teacher in delivering learning comes only from the student's textbook. The lack of understanding of students' spatial literacy, in the end causes students to be less careful in making decisions and also solving spatial problems that occur in everyday life. This research was conducted related to the effectiveness of media maps in social studies learning in class $\mathrm{V}$ students of elementary schools in Metro City. The purpose of this study was to provide an understanding of students' spatial literacy, especially in material related to space in social studies subjects. The type of this study is quasiexperimental research using the design of nonequivalent groups pre test-post test from Fraenkel and Wallen. The design of nonequivalent groups pre test - post test was started by setting the experimental group and the control group, then doing the pre test, followed by giving treatment to the two classes and ending with a post test. The subjects in this study were fifth grade elementary school students in Metro City. Data collection techniques in the form of tests. The research instrument is a spatial literacy test sheet. Data were analyzed using normality test and Mann Whitney test. The results of this study indicate that the effectiveness of using media maps in social studies learning can provide an understanding of spatial literacy of fifth grade elementary school students in Metro City. This can be seen from the increase in the correct number of each indicator of spatial literacy that is given in the form of determining the location, identifying spatial orientation, determining the closest distance and identifying objects through symbols on the map. The results of this study can be a suggestion for teachers and schools to continue to facilitate social studies learning with appropriate media, especially media maps for material related to space, so as to provide students with more understanding of spatial literacy.
\end{abstract}

Keywords: media map, spatial literacy, elementary students.

\section{INTRODUCTION}

Knowledge related to social sciences is very necessary both related to the scope of the discussion, the object being studied, methods and approaches from each of the social science disciplines such as economics, history, sociology, anthropology and geography. In elementary school, the social sciences are integrated in the subject of social studies (IPS). This is further confirmed by Saidihardjo [1] that "Social Studies is a combination result or result of fusion or a combination of a number of subjects such as: geography, economics, history, sociology, anthropology, politics." In this plural aspect, the geographical aspects provide opportunity for students to be able to learn about space and its relationship with student life as a community.

Scientifically, geography is defined as the study of equations and differences in geosphere phenomena with environmental or territorial perspectives in spatial contexts (Sumaatmadja[2]). As explained by National Geography that "Geographic skills provide necessary tools and techniques to think spatially. They can observe patterns, associations, and spatial orders. Geographic representations ... are essential because they assist in visualizing spatial arrangements and patterns"(National Geography Standard, 2012). Maryani [3] (in the UPI Professor's Inauguration speech in 2010) stated that geography learned about space. Human intelligence and skills in utilizing space, will give direction to how nature is modified for survival (Maryani, [4]).

In general, the difficulty of students in understanding spatial concepts is the lack of student activity during learning, the lack of involvement of students in making learning products, and the lack of use of media that can develop cognitive abilities and skills of students. Students will be more interested if in learning teachers provide opportunities for them to grow creativity. In connection with this, the role of the teacher in its efforts to create effective and meaningful learning for students is very important. 
In this study, spatial literacy will be the main focus. What is the specificity of spatial literacy for elementary school children? A best college in the United States, Carleton College formulated that "Spatial literacy is the ability to use the properties of space to communicate, reason, and solve problems," which means that spatial literacy is the ability to use the properties of space in communication, give reasons and solve problems. In this study, to support the achievement of elementary students in terms of spatial thinking, spatial understanding of knowledge can be helped by using map media.

Maps are representations or representations of abstract appearance elements selected from the surface of the earth that have to do with the surface of the earth or celestial bodies, which are generally depicted on a flat and scaled plane (International Cartographic Association, [5]). The National Survey and Mapping Coordination Agency (now a Geospatial Information Agency) defines maps as a vehicle for storing and presenting data on environmental conditions, is a source of information for planners and decision makers at the stages and levels of development (2005). Seeing the definition of the map, Geography learning will be more interesting for students if the teacher uses map media.

Piaget in Budiningsih [6] suggests that the age range of elementary school children who are $7-11$ years old, which is at the concrete operational stage, has the characteristic that children have begun to use clear and logical rules, with objects objects that are concrete. So that in learning the teacher should involve students with something tangible. In this case, the map is a media or tool for elementary students who can show a concrete picture of the earth in detail, making it easier for us to find the location of a location. Sobel in Maxim [7] describes the "small world approach", which is an approach that suggests classroom teachers to introduce their students to the world closest to them first.

The learning activities needed are those that are able to produce the ability to learn, not only to obtain a number of knowledge, skills, and attitudes, but more important is how the students' knowledge, skills, and attitudes are obtained. The activity of reading the map has actually been done a lot by the teacher, but the teacher is only bound to the order from the textbook. Students have not been given many opportunities to explore their ability to read maps. This activity can be started from the nearest environment first, such as a map of the classroom or home environment.

Understanding the closest environment of students, especially understanding of spatial aspects can be maximized with the help of media, one of which is the media map. On the basis of the problems that have been presented, then this research is entitled "Increasing Spatial Literacy of Primary School
Students Through the Utilization of Map Media in Social Studies Learning."

A similar study referred to in compiling this study was a study conducted in Turkey by Yusuf Kilinc with his research title "A Study On The Maps of Skills of Primary School Students: A Case of 7th and 8th Grades." This case study conducted by Kilinc identified how elementary students in using maps? How important maps are in helping many things in human life. For elementary students, getting used to spatial thinking can help them find solutions to their problems. Kilinc gave 29 questions about maps to 194 elementary school students and the results of the Kilinc Study showed $78.9 \%$ of students answered correctly and $21.1 \%$ answered incorrectly.

Mamik Sumarmi from the Open University of Surabaya also conducted a similar study in 2006. Sumarmi's research entitled "Increasing Understanding of Maps through Regional Approaches in Elementary School Social Studies Learning." The study outlined various maps and their uses taught to elementary school fourth grade students and Sumarmi used map of the distribution of tribes, natural resources, and historic heroes' relics as media in social studies learning. As a result, social studies learning has increasingly attracted the attention of students with maps as a medium and is associated with concrete things in students' daily lives.

Furthermore, the formulation of the problem is elaborated in the questions as follows: "How effective is the use of media maps on the spatial literacy of fifth grade elementary school students in social studies learning?"

The purpose of the study using this quasiexperimental approach was to find out the effectiveness of using media maps on the spatial literacy of fifth grade elementary school students in social studies.

\section{RESEARCH METHODS}

The type of research used in this study is quasi-experimental research. Ali [8] argues that quasiexperimental studies are experimental studies, except that there are constraints in fulfilling criteria related to the selection of random sample subjects and random assignment of subjects because research involves humans, such as behavior and social research. This quasi-experimental study using a nonequivalent groups pre-test design - post test design can be described as follows:

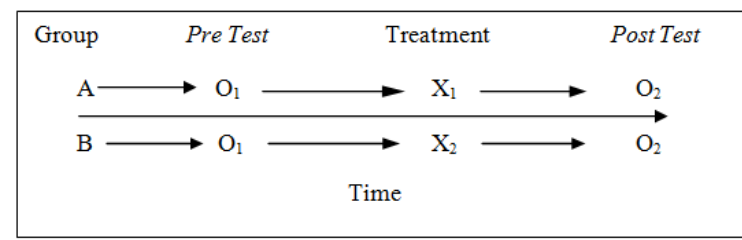

Figure 1. Nonequivalent Groups PreTest-Post-Test Design 
Information:

$\begin{array}{ll}\mathrm{A} & : \text { Experimental class } \\ \mathrm{B} & : \text { Control Class } \\ \mathrm{X}_{1}: & \text { Treatment (treatment) utilizes map media } \\ \mathrm{X}_{2}: \text { Treatment (treatment) does not use map media } \\ \mathrm{O}_{1}: \text { Initial test before treatment } \\ \mathrm{O}_{2}: \text { Final test after treatment }\end{array}$

Subjects in this study were Class V elementary school students in Metro City with of SDN 10 Metro Timur, SDN 5 Metro Selatan, SDN 4 Metro Utara and SDN 6 Metro Pusat control class. The instrument used in this study is a test of spatial literacy of students. The first instrument used to find out the learning outcomes included pre-test (initial test) and post-test (final test), both in experimental and control classes. The collected data was analyzed using the help of SPSS version 18 for Windows. The test used to test the hypothesis in this study is the t-test and Mann Whitney test.

\section{RESULTS AND DISCUSSION}

The results in this study were descriptive results of the pre-test data of the experimental class and control class, descriptive results of post-test data on experimental class and control class analysis of the results of the experimental class and control class pretest, analysis of experimental test results and control classes, different test Mann Whitney test to test the hypothesis. The results of the normality of the pre-test and post-test of the two classes are shown in Table 1.

Table 1

Description of Experimental Class Pre Test Results

Tests of Normality

\begin{tabular}{|c|c|c|c|c|c|c|c|}
\hline & \multirow[t]{2}{*}{ Class } & \multicolumn{3}{|c|}{$\begin{array}{c}\text { Kolmogorov- } \\
\text { Smimov }^{\mathrm{s}}\end{array}$} & \multicolumn{3}{|c|}{ Shapiro-Wilk } \\
\hline & & Statistic & $\mathrm{df}$ & Sig. & Statistic & Df & Sig. \\
\hline \multirow[t]{4}{*}{$\begin{array}{l}\text { Students } \\
\text { Spatial } \\
\text { Literacy }\end{array}$} & $\begin{array}{l}\text { Experimental } \\
\text { Pre-test } \\
\text { (Map Peta) } \\
\end{array}$ & .160 & 64 & .000 & .942 & 64 & .005 \\
\hline & $\begin{array}{l}\text { Experimental } \\
\text { Post-Test } \\
\text { (Map Peta) } \\
\end{array}$ & .134 & 64 & .006 & .959 & 64 & .034 \\
\hline & Control Pre-test & .107 & 59 & .089 & .969 & 59 & .130 \\
\hline & Control Pos-Test & .151 & 59 & .002 & .928 & 59 & .002 \\
\hline
\end{tabular}

Because the significance is $<0.05$, it can be concluded that the data are not normally distributed, so the researchers used the Mann Whitney test.

Basic decision making.

1. If the Asymp value is Sig <0.05, then the hypothesis is accepted.

2. If the Asymp value is $\mathrm{Sig}>0.05$, the hypothesis is rejected.
Hypothesis: There are spatial literacy differences between classes that use map media and classes that do not use pedia maps.

Table 2

Mann Whitney test results

Test Statistics ${ }^{\mathrm{a}}$

\begin{tabular}{|l|l|}
\hline & Spatial Literacy \\
\hline Mann-Whitney U & 1127.000 \\
Wilcoxon W & 2897.000 \\
Z & -3.888 \\
Asymp. Sig. (2-tailed) & .000 \\
\hline
\end{tabular}

Based on the output of the Statistics Test it is known that Asymp. Sig. (2-tailed) of 0,000<0,05. Then it can be concluded that the hypothesis is accepted. "Thus it can be said that there are differences in spatial literacy between classes that use map media with classes that do not use pedia maps. Because there are significant differences, it can be said that there is an influence of the use of media maps on the spatial literacy of fifth grade elementary school students in social studies learning.

Use of Map Media can Improve Spatial Literacy of Students

The pre-test and post-test data that have been collected, were analyzed by predetermined testing and showed that spatial literacy increased higher in the class that did IPS learning by streamlining the use of map media. This means that the map successfully performs its tasks well as a learning medium. As revealed by Gerlach \& Ely in Arsyad [9] that the media if understood broadly is human, material, or events that build conditions that make students able to obtain knowledge, skills, or attitudes. Through maps students can know the conditions from the past to the present, so they can predict future conditions. This will affect the increasing intelligence of students in solving problems and making decisions in everyday life, as previously explained that spatial literacy also summarizes these two abilities.

Abdurrachman [10] in his dissertation describes the benefits that can be obtained by students after reading the map, namely:

1. The map makes it easy to identify the location, location, distribution and spatial orientation. These elements are related to direction, distance and form;

2. maps can facilitate and clarify understanding of concepts relating to direction, distance, location, area and form, if used appropriately at the time of the teaching-learning process;

3. a map is a tool for expressing ideas, including a person's perception of the environment in the form of spatial constructs; 
4. maps can improve, change and enrich the construct of one's space about the environment.

Seeing the benefits of reading the map, the map is a medium that can improve the spatial literacy of students. Education for All Global Monitoring Report in Maryani [4] reveals that the term literacy means:

a) literacy as an autonomous set of skills;

b) literacy as applied, practiced and situated;

c) literacy as a learning process;

d) literacy as text.

From this understanding it can be seen that in learning literacy will form a unity of skills, application and fluency in certain situations, as well as meaningful learning processes. Likewise with social studies learning by utilizing map media, students will be trained to think spatially. The National Research Council [11] also explained that by spatial thinking, we will get three things, namely spatial concept, spatial representations and also spatial reasoning. These three things will lead us to think more directed, see space from a 3-dimensional perspective, and help us to make decisions.

In addition, Kerski in Zwartjes [12] suggested that "summarizes spatial thinking skills and characteristics of human impact in time and at appropriate scale. In fact this is real geography: the ability to think about the earth, the activities of people and the interaction between the two. Thinking spatially is more than knowing where things are located, it's about asking for geographic questions: why there, how originated and what if ...".

That with spatial thinking students will be trained to answer geographical questions such as why there, how it works or what and so on. Based on the above theory, the effectiveness of the use of media maps in social studies learning in class $\mathrm{V}$ is considered as the right treatment to help students improve their level of thinking to find solutions to the spatial problems around them. It can be concluded that the map media can have a good impact on the spatial literacy of fifth grade elementary school students in Metro City.

\section{CONCLUSION}

Conclusion in this research are:

Learning social studies with the effectiveness of using media maps can have a good impact on the spatial literacy of fifth grade elementary school students in Metro City.

Suggestions that can be given after doing this research are:

1. It is expected that the next researchers can conduct research with the object of research that has never been studied before relating to the problem of space seen from the point of view of learning conducted by elementary school students.
2. For readers in general, it is expected that this research can add references related to space, especially in the spatial aspects of literacy of elementary school-age students.

\section{REFERENCES}

[1] Saidihardjo \& Sumadi HS. (1996). Konsep dasar Ilmu pengetahuan Sosial. (Buku 1). Yogyakarta : FIP IKIP.

[2] Sumaatmadja, N, dkk., (2004). Konsep Dasar IPS. Jakarta: Universitas Terbuka.

[3] Maryani, E. (2010). Dimensi Geografi Dalam Kepariwisataan dan Relevansinya Dengan Dunia Pendidikan. Bandung: UPI.

[4] Maryani, E. (2015). Kecerdasan Ruang Dalam Pembelajaran Geografi. Bandung: UPI.

[5] ICA. (2003). International Cartographic Association. Swedia.

[6] Budiningsih, A. (2004). Belajar dan Pembelajaran. Penerbit Rinika Cipta, Yogyakarta.

[7] Maxim, George W. 2010. Dynamic Social Studies for Constructivist Classroom: Inspiring Tomorrow's Social Scientists (Ninth Edition). Boston: Allyn \& Bacon, Pearson.

[8] Ali, M. (2011). Memahami Riset Prilaku dan Sosial. Bandung: Pustaka Cendekia.

[9] Arsyad, A. 2013. Media Pembelajaran. Jakarta: PT. RajaGrafindo Persada.

[10] Abdurrachman, M. (1985). Hubungan Antara Penggunaan Peta Geografis dengan Image Keruangan dan Pemahaman Siswa Tentang Konsep-Konsep yang Berkaitan dengan arah, Jarak, Letak, Luas dan Bentuk. Bandung: Universitas Pendidikan Indonesia.

[11] NRC (National Research Council). (2006). Learning to Think Spatially. Washington D. C. The National Academies Press

[12] Kilinc, Y. (2011). A Study On The Maps Skills Of Primary School Students: A Case Of $7^{\text {th }}$ And $8^{\text {th }}$ Grades. Ohio. Ozean Publication. European Journal of Education Studies Vol. 3 No. 2.

[12] Zwartjes, L. (2008). iGuess: Introducing GIS Use in Education in Several Subjects. [online]. Tersedia di http://www.herodot.net/conferences/ ayvalik/papers/geotech03.pdf (4 November 2014).

[14] Sumarmi, M. (2006). Peningkatan Pemahaman Peta Melalui Pendekatan Wilayah Dalam Pembelajaran IPS SD. Surabaya: UPBJJ. Jurnal Penelitian Didaktika Vol. 1 No. 1 Maret 2006: 75-92. 